\title{
Pluralism Consciousness for Students at Muhammadiyah University of Kupang Through Multicultural Education
}

\author{
Syahrul $^{1} *$ Siti Susanti M. Djaha ${ }^{2}$
}

\author{
${ }^{1}$ Sociology Education Department, Universitas Muhammadiyah Kupang, Kupang, Indonesia \\ ${ }^{2}$ English Letter Department, Mentari Foreign Language Kupang, Kupang, Indonesia \\ *Corresponding author. Email: syahrul@unmuhkupang.ac.id
}

\begin{abstract}
The Muhammadiyah University of Kupang (UMK) is famous as a pluralistic institution because this campus has Islamic ideology, but it is dominated by Christian students ( $75 \%$ Christian and 25\% Moslem). The pluralism is increasingly strengthened through the vision of a multicultural institution as well as the application of multicultural education. The research was focused on the application of multicultural education to raise the pluralistic consciousness at the Muhamamdiyah University of Kupang. The study used qualitative research and purposive sampling to select subjects, namely Islamic, Protestant, Catholic students, and lecturers. The data was collected through in-depth interviews, observations, and field notes which were analyzed in one circle among data collection, categories, reading, noting, description, classification, interpretation, and visualization. The result of the study shows that implementation of multicultural education in UMK was divided in two approaches, namely (1) wisdom approach which consists of moral, social, and local wisdom carried out outside the class, and (2) the curriculum consists of contributions, additives, transformative approaches and social actions carried out in classes.
\end{abstract}

Keywords: Pluralism, Multicultural Education

\section{INTRODUCTION}

The Muhammadiyah University of Kupang (UMK) has risen pluralism consciousness through multicultural education. This is reinforced in institutional vision and mission that contains multicultural insights. Multicultural issues arise because of the number of non-Muslim students at UMK more than Muslim students (non-Muslims 75\% while Muslim 25\%). Before 2018, Muhammadiyah University of Kupang has done various programs to introduce pluralism university, namely through the newspaper of Cakrawala NTT and AIK (Al-Islam Kemuhammadiyaan) learning to non-Muslim students [1]. In observation, the programs do not have the multicultural characteristic because AIK learning seems hegemony and oppress to non-Muslim students such as pushing into Islamic ideology. On the other hand, several non-Muslim students complain about AIK subjects because they were intolerant with non-Muslims, and they tend to feel the Islamization. Therefore, to maintain religious pluralism at the Muhammadiyah University of Kupang, they put multicultural in the vision and mission of the institution. Moreover, the vision and mission are supported by the curriculum through multicultural education [2], [3].

In 2002, pluralism consciousness at UMK was also formulated in the National Conference of Muhammadiyah in Denpasar Bali, after that they continued on the same Conference on January 29-31, 2000 in Malang. The conferences decided on the importance of pluralism in Muhammadiyah. It was supported by the book which was published in Majelis Tarjih and Islamic knowledge development about the Social Relation of Religious Constitution (Tafsir Tematik) [4]. The formulation was very long because there were pros and cons among representatives of Muhammadiyah, and the result was the ides of cultural propaganda. The program was conducted by several institutions of Muhammadiyah, such as developing educational infrastructure that became multicultural conception. It was caused by the era of globalization requiring a human right that should be faced by Muhammadiyah [5], [6]. As a result, pluralism consciousness was very important to emphasize to all Muhammadiyah institutions [7].

UMK is one of the educational institutions of Muhammadiyah which showed responsible for religious pluralism. This issue was supported by several Muhammadiyah figures who gave positive appreciation to pluralism and the others refused. Figures such as Ahmad Syafii Maarif, Amin Abdullah, Abdul Munir Mulkhan, and Muslim Abdurrahman can represent Muhammadiyah thinkers who agree with pluralism in UMK. Meanwhile, activists of Muhammadiyah who disagree with pluralism such as Muhammad Muqodas, Yunahar Ilyas, and Musthafa Kamal Pasha. They assume that pluralism was contrary to Islam. Even the discourse of pluralism in Muhammadiyah is considered to be very unsettling. Different perfective in Muhammadiyah figures is very interesting to study and to see how involved UMK to grow pluralism consciousness [8].

Minimizing misconception to pluralism discourse at UMK needs to understand the four typologies of religious pluralism, they are:

(1) Pluralism is different from diversity but energy is the engagement with diversity. Religious diversity is given, whereas religious pluralism is an achievement that 
should be actively pursued. (2) Pluralism is not only tolerance but also actively search to understand diversities. (3) Pluralism is different from relativism, but it is effort the encounter of commitments. (4) Pluralism is based on dialogue. It involves two people or more to speak and to hear. Both processes to mine about the same understand and different reality. Therefore, the importance of the dialogue is commitment and willingness to always sharing and criticizing [8]-[13].

Moreover, Tafsir Tematik book of social relationships among religions was resulted by the $24^{\text {th }}$ Tarjih Muhammadiyah National Conference which took place on January 29-31, 2000 in Malang said that pluralism in theological discourse had three definitions, namely: (1) pluralism is the objectivity of societies, religion and culture, and an actual plurality (Bhinneka Tunggal Ika) in Indonesia. (2) Pluralism is a political connotation of secularism, namely separating religion from the public affair, showing antireligious phenomena, unrecognizing religions, and respecting and giving all religious opportunities for development. (3) The term pluralism refers to a paradigm that said that the end of all religions is the one purpose [4].

Realizing pluralist consciousness to Muhammadiyah generally has been done by the Muhammadiyah figures through "cultural da'wah" or in an educational institution, it is known as multicultural education. Moreover, Muhamamdiyah University of Kupang has been conducting pluralism in vision and mission university, faculties and departments, and developing into the curriculum through multicultural education [2], [14]. Therefore, Muhammadiyah University of Kupang committed to devolving a lifestyle of pluralism. This policy has been conducted as public service to students of various social backgrounds such as race, ethnicity, language, religion, and economics. As a result, Muhammadiyah University of Kupang has been seriously responded to the life of pluralism and multiculturalism in the province of East Nusa Tenggara. Implementation of multicultural education in Muhammadiyah institutions will grow pluralism consciousness to their members [15]. The spirit of pluralism is very important to them who are living in minority places, such Islamic education (Muhammadiyah University of Kupang) has more Christian students than Muslim students, while they are living in Kupang City, East Nusa Tenggara Province that has Christian majority [16]. However, these phenomena showed that although the Muhammadiyah University of Kupang is Islamic ideology, it has emphasized pluralist consciousness to other religions through multicultural education such us accepting and servicing Christian students. Multicultural education uses learning strategy, method, and approach which can be accepted by all religions, and which can be integrated into class, curriculum, and subjects, therefore all students got equal treatment [17]. On the contrary, Muhammadiyah University of Kupang is not inclusive essentially because learning subjects and material are unsuitable for Christian students.

Implementation of multicultural education at the Muhamamdiyah University of Kupang should be referred of four approaches by Banks, they are: (1) the contributory approach bring a social-cultural element to educational institutions, (2) the additive approach is adding learning materials without changing the curriculum structure, (3) the transformative approach change curriculum structure for students can study materials and societies from several cultural perspectives, (4) social action approach is making decision and action including personal and social problems [18], [19].

The research had shown that although Muhammadiyah emphasized ideological Islam, the founding father of Muhammadiyah was generally available and tolerant for social traditions and other religions. Moreover, research of Efendi and Suswanta showed that although there was the prevention of pluralism in Muhammadiyah institutions, it will not diminish the spirit of the Muhammadiyah University of Kupang becoming the pluralism university. This effort can be seen in vision and mission, and the curriculum of this university. Moreover, they have been introduced to the Muhamamdiyah University of Kupang as a pluralism and multiculturalism university through social media [20].

This shows a challenge and a different understanding of pluralism and multiculturalism at the Muhammadiyah University of Kupang. Therefore, the new rector revised the policy of vision and mission institution to grow pluralism consciousness which is conducted through the curriculum, particularly multicultural education. As a result, this study has investigated how to grow pluralism consciousness through multicultural education at the Muhamamdiyah University of Kupang.

\section{METHOD}

The study used a qualitative method which was based on verstehen to interpret in social realities at the Muhammadiyah University of Kupang such as social interaction, administrative service, learning process, a curriculum, social relation between students and lecturers, students and students, lecturers and lecturers [21]. The subjects were selected by purposive samplings such as Islamic and Christian students, staff, lecturers, deans, and directors. Data were collected by (1) observation to search the implementation of multicultural values, (2) interviewing students to know how to apply multicultural education, interview rector and dean to know an achievement of the vision of multicultural education, and (3) noting the unique experiences at Muhamamdiyah University of Kupang. The way of data was analyzed into the circle of analysis, namely, the analysis engaged several data which moved into one circle such us organizing data, reading, noting, description, classification, interpretation, and visualization [22].

\section{RESULTS AND DISCUSSION}

The emphasis of pluralism consciousness at the Muhamamdiyah University of Kupang has been conducted since Sandi Maryanto became the Head of the University. However, pluralism issues in this era are only a discourse that is introduced to the public through social media. After Zainur Wula was elected as the surrogate of the Head of University in 2017 , pluralist issues are increasingly clear because it is not only a discourse, but it is becoming an ideology, vision, and mission of the institution and curriculums. Moreover, pluralism is integrated into the learning process through multicultural education. On the other hand, the Muhamamdiyah University of Kupang is introduced as a pluralism institute in several regencies 
particularly in NTT Province through social media, newspapers, local TV, and radio.

Being a pluralism institution is not easy for the Muhammadiyah University of Kupang because several lecturers who have a different interpretation of pluralism. Several lecturers interpreted pluralism as a misguided ideology because it is a religious union. Meanwhile, they consider pluralism as a liberal virus that is dangerous for Muhammadiyah institutions. The lecturer group is usually preaching at Ahmad Dahlan Mosque considered that pluralism is a controversial issue in Islam, whereas the lecturer group is rarely preaching at Ahmad Dahlan Mosque supported pluralism, while they more tend to research and scientific publication. As a result, there are different interpretations of pluralism at the Muhammadiyah University of Kupang. Lectures who supported pluralism and multiculturalism has two reasons, such as:

First, they considered that pluralism which is the opposite of Islam taught all religions alike. It means that other religions which are believed by several people are refused, but it does not refuse the existence. Second, they considered Islam is a religion that taught all aspects of life. According to MKCHM, Islam has four aspects of ideology, namely: Aqidah, Ibadah, Akhlaq, and Mu'amalah Dunyawiyah [3]. As a result, this ideology is not a dichotomy of religion and non-religion because both can be engaged. Religion is basic to do something and to recognize everything as a worship of God.

Students at the Muhammadiyah University of Kupang have several religions, races, ethnicities, languages and cultures, but it has three sensitive issues, namely (1) religion such as Islamic, Catholic and Protestant. Muslim students are becoming the minority because they are from Java, Bugis, and Bima, whereas Catholic and Protestant are the majority because they are the local people of East Nusa Tenggara province. On the other hand, (2) race also extremely influences. It can be seen from colour and hair such as black and brown skin or curly and straight hair. Moreover, (3) languages are different because each region in this province has a language, while there are trans migrant languages such as Bugis, Bima, and Java.

The implementation of multicultural education at the Muhammadiyah University of Kupang is carried out by the Department of Sociology Education because it can be seen in curriculum and vision. Implementation of multicultural education was started in 2017 when the head of University claimed and indicated multiculturalism as a vision of Muhummadiyah University of Kupang. As a result, multiculturalism is not only symbolic but also part of the curriculum. In Table 1, I show the implementation, approach and output of multicultural education through several stages.

Table 1. Implementation of Multicultural Education at UMK

\begin{tabular}{|c|c|c|c|}
\hline $\begin{array}{l}\text { Implementation of } \\
\text { Multicultural } \\
\text { Education }\end{array}$ & \multicolumn{2}{|c|}{ Approaching } & Output \\
\hline $\begin{array}{l}\text { Religious training of } \\
\text { new student }\end{array}$ & \multirow{3}{*}{$\begin{array}{l}\text { Wisdom } \\
\text { approaches }\end{array}$} & Moral wisdom & $\begin{array}{l}\text { Students receive the religious difference, and they became a } \\
\text { religious person who obeys the role of their religion }\end{array}$ \\
\hline Campus environment & & $\begin{array}{c}\text { Social } \\
\text { wisdom }\end{array}$ & $\begin{array}{l}\text { Students defend their religious identity, namely, Christian students } \\
\text { still said "Shalom" although they greet Islamic lectures and } \\
\text { students, whereas Islamic students also said "Assalamualaikum" }\end{array}$ \\
\hline $\begin{array}{l}\text { Muhammadiyah } \\
\text { cultural propaganda }\end{array}$ & & Local wisdom & $\begin{array}{l}\text { Students did not leave their local culture and they actively } \\
\text { socialized their local culture such as eating sirih pinang (Mamat } \\
\text { Tradition) as a symbol of the host's appreciation for their guest }\end{array}$ \\
\hline Curriculum & \multicolumn{2}{|c|}{$\begin{array}{l}\text { Approaches of contribution, } \\
\text { additive, transformation, and } \\
\text { social action }\end{array}$} & $\begin{array}{l}\text { Reducing Islamization to Christian students, such as avoiding } \\
\text { Islamic indoctrinations in AIK and Arab Language subject, and } \\
\text { growing of pluralism consciousness during the learning process. }\end{array}$ \\
\hline
\end{tabular}

\subsection{Religious Multicultural Education}

In religious multicultural education, new students have introduced multiculturalism and pluralism [11], [23], [24]. They studied the sense of multiculturalism that contends in the vision and mission of the Muhamamdiyah University of Kupang. Religious multicultural education is an adaptable process to new students, academic processes, academic culture, and student organizations. It took place during a week which was divided into four days to the institution and two days to faculties. The strategy to carry out multicultural learning used collaborative learning in the main hall of campus which was presented by all new students. In this place, new students were taught several theories of multiculturalism and pluralism.

Religious multicultural education has reformed pluralism consciousness through the moral wisdom approach. The value of local wisdom as an impact of mutual respect from several religions among students. Every student should reduce everything which triggers conflict, namely: (1) historical prejudice, (2) discrimination, and (3) superiority and inferiority. On the other hand, an approach that is usually used is a communicative approach. Students have various religious which can be used as learning material to be discussed. Lecturers avoided conferring morals in Islam, Protestant and Catholic. As a result, they can find the moment to know and to honour the difference between Islam and Christianity.

The approach of moral wisdom in the Muhamamdiyah University of Kupang is a study that treated the soul of the students through the dialogue method. Therefore, the attitude, action and thinking can be understood and accepted as different faith and spiritual value on each religion that is essentially invited into the moral of God and humanist. They are mentally trained to become pluralism and to make them get knowledge which is not only to satisfy their curiosity and 
intelligence or to get material advantages but also they grow rational thinking of students who were virtuous, wise and religious for family, country, and society.

The product of the moral wisdom approach at the Muhammadiyah University of Kupang is a theory of multicultural learning that can engage Muslim and Christian students in an institution. It can be proofed from the interview with a student,

I am Protestant. My friends have asked me a question, why you study at the Muhammadiyah University of Kupang? While it is an Islamic institution, and I answered that the Muhammadiyah University of Kupang is an Islamic university, but almost all students who studied are Christian. This university also did not discriminate against the students [25].

The lecturers treated us as well as Muslim students. They did not distinguish between Muslim and Christian students. Meanwhile, we also have been gained our rights, such we can learn Protestants in the first semester and we have Protestant organizations at Muhammadiyah University of Kupang (PKMP/Organization of Protestants Students) [26].

This interview shows that the implementation of multicultural education has been conducted at the Muhammadiyah University of Kupang, namely (1) multicultural learning contained values of pluralism and universalism which is unlimited by geographical scope and ideology, therefore all religions can be accepted in this institution, and (2) multicultural learning is religious because all students are guided into their religion by the lecturers who are same as religion.

\subsection{Multicultural Education Through Institutional Culture}

Multicultural education was carried out to raise religious consciousness for all students, namely: Muslim students greet with "Assalamualaikum" and Christian students greet with "Shalom". It was emphasized as an institutional culture to avoid misconception of multiculturalism because several students and lecturers consider that if Christian students say "Assalamualaikum" when they greet their lecturers and friends is part of the multiculturalism concept. On the contrary, this made alienation to Christian students because it is only tolerant, and it does not include multiculturalism and pluralism consciousness. The real pluralism and multiculturalism are when Christian students greet their friends and lecturers with "Shalom". Therefore, Christian students at UMK are not forced to say "Assalamualaikum" and other Islamic ideologies. Emphasizing pluralism also appeared in a dormitory which not only provided the dormitory for Muslim students but also for Christian students.

Administration services emphasized a pluralism consciousness through the social wisdom approach at the Muhammadiyah University of Kupang. Social wisdom is used as networking in socialization and interaction between students and other students, lecturers and students, and students and staff. According to a student, the condition of the Muhammadiyah University of Kupang was
The institutional culture was very good, therefore we as Christian students were very happy on campus because there was not intimidation between students and lecturers. At this time, the campus was safe and peaceful because there was conflict, and it made us comfortable [27].

This showed that the value of social wisdom at the Muhammadiyah University of Kupang can erase social conflicts. Therefore, the order of social life in this campus has manifested into social behaviour such as respecting individual, community, majority and minority community. According to an interview with students, it has been emphasized.

I thought that tolerance at the Muhammadiyah University of Kupang was very high and prominent. It made us happy as a Christian student especially my experience at the department of sociological education because there was no prejudice among students and lecturers, whereas I found a high brotherhood between students and lecturers. Social values which were emphasized in this campus were very precise because it grows multiculturalism [28].

This shows that institutional culture was produced by a social wisdom approach at Muhammadiyah University at Kupang. This also formed a pluralism and multiculturalism campus among primitive society in this Province, while they are not fanatic to one culture and religion such as Alor, Atoni, Bajawa, Ende, Kemang, Lamaholot, Manggarai, Ngada, Rote, Bima, Bugis, and Java. On the other hand, the social wisdom approach reduces the caste system at the Muhammadiyah University of Kupang, such there is not the social distance between students and lecturers, staff and lecturers. They are gathering in various activities such as futsal, tennis table, artworks, recreation, and others. They also held a party and eat together on campus without thinking about occupation and degree. Therefore, the growing slogan DONKRYW (togetherness of lecturers, staffs and students). Moreover, this gathering is not only to lecturers, staffs and students but also to securities and cleaning services. The gathering made better several events because all members can present, and they have not hesitated to interact with others.

\subsection{Multicultural Education Through Cultural Da'wah}

The cultural da'wah is a learning approach that is used to grow pluralism consciousness at the Muhammadiyah University of Kupang. It is carried out using the local wisdom approach. Cultural da'wah has been going on for a long time which is usually conducted in seminars and other studies using the theme of local wisdom of Timor culture. Moreover, Muhammadiyah University of Kupang applied an important theme that related the local wisdom values of Timor. He also carried out multicultural learning such as training and workshop to lecturers and students. On the other hand, cultural da'wah aimed to emphasize pluralism consciousness. It is done to increase consciousness on the local wisdom value of Timor culture. As a result, multiculturalism at the Muhammadiyah University of 
Kupang is not only as a symbol and a theory but also as an ideology and learning.

Cultural da'wah also carried out through the Hal Bin Hal event. This is one of tradition every year which was held at Muhammadiyah University of Kupang after celebrating Eid al-Fitr as purpose to transform forgiveness toward humankind for all students and lecturers. Therefore, the event was presented by all Christian students. According to the Christian student,

Hal Bin $\mathrm{Hal}$ at the Muhammadiyah University of Kupang was not too Islamic because we were from Catholic enjoyment in this celebration. Moreover, the event was too general, and the theme put in multicultural values, so Islamic ideology was not tendencies. As a result, the event was very interested for us as Christian students [29].

This event reduced the negative perspective for Islamic religion in Timor society. Forgiveness toward humankind that is informed into the institutional culture has grown multiculturalism and pluralism consciousness. This also informs equality between students and lecturers, such the lecturers apologize to students, whereas the students apologize to the lecturer. Hal Bin Hal carried out in several places, but the Muhammadiyah University of Kupang is different from others because the event put several traditional cultures from Timor such as singing and dancing together by the Timor art. The outcome of local wisdom is granted the Muhammadiyah University of Kupang as an institution that preserved the local culture of Timor. Although global culture influenced, he is very selective to develop the local wisdom of Timor. As a result, multicultural education internalized the local culture of Timor into the curriculum and learning process.

\subsection{Multicultural Education Through Curriculum}

The integration of multicultural education in the curriculum is a form of vision and mission of the Muhammadiyah University of Kupang. The aim of the multicultural curriculum is (1) to grow pluralism consciousness to all students, institutions, and social interaction. It is preferred to students and lecturers when they gather on the campus because most of them are different religions and cultures, and (2) to grow multicultural in the learning process and multicultural skill. It is preferred for students who want to be a teacher when they graduated at the Muhammadiyah University of Kupang.

Implementation of multicultural education in the curriculum aimed to develop multicultural values either inside the learning process or outside the learning process. In the learning process in the classroom, lecturers do not discriminate their students such as ethnicity, gender, religion, race, and culture. It will be shown in an interview with one of the students,

In the learning process, our lecturers do not discriminate us such as comparing religion between Islam and Christianity, culture, race, ethnicity, and gender. We also respected our friends, such as Islamic students togetherness with Christian students in the learning process, whereas Christian students respect too Islamic students [30].

This learning process has integrated into the curriculum at the Muhammadiyah University of Kupang. Therefore, he is not only as an educational institution to a concept, study and develops knowledge in a monoculture perspective, but he has become arena multiculturalism. The substance of multicultural education is to emphasize pluralism consciousness to students and all people who members at the Muhammadiyah University of Kupang in the same positions. As a result, the students knew that there are many different ways, but the purposes and values are the same. Moreover, they can study to accept pluralism into welfare life, and finally, the students awarded that pluralism is not a problem, but it is a gift from God.

The implementation of multicultural education in the classroom is done by integrating into several subjects and learning approaches. It carried out by using four kinds of multicultural approach [31], namely: First, the contribution approach is used to select textbooks which are used put into reference books which contain about culture and local wisdom of Timor Island. The purpose of the approach is to raise knowledge about Timor cultures because there is not specifically reference books which study about Timor culture. Therefore, multicultural education at the Muhammadiyah University of Kupang specifically studies and internalize a culture and local wisdom of Timorese into the learning materials. The lecturer developed the learning materials by offering the cultural characteristics of Timor Island. This approach is applied to students with using several methods, namely: (1) introducing several custom home from Timor, such us every student tells the histories and the tradition of costume home of Timor and the lecturer carried out a study tour in several villages that still preserved costume home of Timor. (2) Lecturer invited the students to know different religion such as working together in several Churchs and mosques in Kupang City. (3) Knowing several important vocabularies in Timor language as support to introduce in the national language, such as beta, Katong, Besong, Nona, Nyong, and Maitua.

Second, the additive approach is adding other cultures outside of Timor without omitting values, cultures, and local wisdom into the curriculum of multicultural education, namely: (1) lecturer tell his experiences and histories about Bugis and Timor marriage which has a similar tradition, but it is a different name, such Bugis is called Uang Panik, while Timor is called Belis. (2) Edding local wisdom values into learning materials such as Mamat tradition (eating betel nut) which is done by Timor people as an honour when they serve their guests in the house and ceremony. This approach is done to develop broad insight about pluralism and local wisdom to students such as becoming an inclusive teacher, accepting differentiation, becoming tolerant, and appreciating the others.

Third, the transformative approach is to compare several understands and perspectives of culture and local wisdom of Timor with other regions. It aimed to open student insights about different cultures in Indonesia. In the learning process, students dialogue and argue with the lecturer to build social interaction and to raise knowledge. This is named as a multiple acculturation process [31]. It is also done with (1) making group discussion, such every group consists of 
several students who are different backgrounds such as ability, gender, religion, and race to learn each other strengths and weaknesses. (2) The lecturer invites their students to give analyzes about a social fact, social action, and social interaction such as suicide bombing, inequality, vandalism, and juvenile delinquency, where lecturers gave chance the student to express their perspectives. (3) The students are accustomed to help each other in religious activities, such as working together to clean the Church and Mosque.

Fourth, the social action approach is done in the learning process such as lecturers and students make a relationship without religious differences and social distances. This purpose to the students to have the knowledge, value, creativity, and social action at the Muhammadiyah University of Kupang. In this approach, a lecturer is the agent of social change who raises democratic, humanist, and student powers.

\subsection{Integration of Pluralism Consciousness in Multicultural Education}

Lecturers have a different perspective of pluralism and multiculturalism at the Muhammadiyah University of Kupang because they are different ideologies such as conservatism, liberalism, and criticism [19]. Conservative multicultural education is more influenced than liberal and critical at the Muhammadiyah University of Kupang. It is difficult to avoid because most of the lecturers are very fanatic with their community. This fanaticism is influenced by histories and modernization of religious sensitivity between Islam and Christian [24]. To build a harmonious relation, they used tolerance among students. However, tolerance is different from pluralism and multiculturalism [32]-[34]. The misconception of pluralism and multiculturalism is often showed by Christian students when they say "Assalamualaikum" to Muslim lecturer and student. This is tolerance, but it is not pluralism and multiculturalism because essentially the Christian religion also should greetings "shalom" [35]. Therefore, to make the institution became pluralism and multiculturalism, every student greets in their religion custom even with people of different religions to avoid alienation in their religion [16].

The Muhammdiyah University of Kupang is claimed as a pluralism and multiculturalism institution because there are several religions, languages, and cultures, while he is Islamic ideology, but Christian students are more than Muslim students. It is as a benchmark of multicultural issue, while it is different from the multicultural concept of James Bank and Bhikuk Pareh because multiculturalism not only to recognize physical differences but also metaphysical differences [18], [36]. The real data showed that there are many Christian students studied at the Muhamamdiyah University of Kupang because, in East Nusa Tenggara Province, Islam is a minority. On the other hand, many Muslim students continue to study in Celebes and Java. Therefore, he should accept Christian students to survive and avoid the lake of students. Muhammadiyah institutions in several islands accepted non-Muslim students, but it is just a few non-Muslim students, and they used different policies such as the learning process, learning material, and dress code. Meanwhile, like the Muhammadiyah University of Makassar, Christian women are required to wear the hijab, whereas, in the Muhamamdiyah University of Kupang, Christian women are not required to wear the hijab. Instead, they dress based on their respective religion and culture.

However, Multicultural and pluralism consciousness is only understood as a pluralist institution because the Muhammadiyah University of Kupang accepted many Christian students, but they only recognized as "exist" not for "being". "Exist" can be determined as Christian students are accepted physically in campus, whereas "being" can be determined as Christian students are accepted physically and metaphysically at Muhammadiyah University of Kupang [35], [37], [38]. These can be divided into two categories, namely: (1) if Christian students study only to fulfil the quota of admission of new students, administration, and benefit from tuition, it is mean that Christian students are only recognized as "exist". (2) On the contrary, if Christian students are given structural and democratic services, no discriminations, no tendencies, no obligation to Christian students studying Arabic, and Kemuhammadiyaan, it means "being".

Emphasizing pluralism consciousness at the Muhammadiyah University of Kupang is not easy because there are many obstacles such us (1) many lecturers who do not know multiculturalism and pluralism concept and many oppressions to the student using a uniform. One of the departments obligated the students to wear uniforms after that other departments follow it. As a result, all students at the Muhammadiyah University of Kupang are obligated to wear the uniform. (2) Many lecturers only accepted multiculturalism as a concept, while they have not applied. It is caused by they do not know how to integrate into the learning process. On the other hand, they violate the vision of multicultural institution such as pushing the students and lecturers to wear the uniform, even multiculturalism and pluralism are the antitheses of uniformity. (3) There is a misconception of multiculturalism at the Muhammadiyah University of Kupang because they carried out the national seminar of multiculturalism without presented the expert of multiculturalism. Instead, they presented the speakers from a politician. As a result, multiculturalism and pluralism consciousness is not clear, and the multicultural vision is very difficult to be achieved at the Muhammadiyah University of Kupang.

This shows that the implementation of multicultural education is not easy because of many obstacles in the learning process at the Muhamamdiyah University of Kupang, namely: (1) socio-cultural aspect show challenge from conservative groups. Most of them are lecturers and students who are from radical groups. They are refuse pluralism and multiculturalism because they assumed that multiculturalism and pluralism are different from Islamic ideology. Thus they have not recognized pluralism and multiculturalism. (2) The political aspect shows that the rector as a policymaker is not easy to combine several visions because most of the students are from Christian, whereas the Muhammadiyah University of Kupang is based on Islamic ideology [24]. (3) The educational aspect shows that the institution is confused to apply multicultural education because most of the lecturers do not know how to apply multiculturalism into the learning process and curriculum [2], [3], [20]. 


\section{CONCLUSION}

The policy to grow pluralism consciousness through multicultural education has done, but it is not carried out maximally because several lecturers did not know and understood multicultural education either theoretically or practically. Meanwhile, pluralism and multiculturalism knew as acceptance because Christian students are accepted at the Muhamamdiyah University of Kupang. On the contrary, it is different from multiculturalism and pluralism concepts because they should not oppress Islamic ideology to Christian students. Moreover, it is mean that pluralism at the Muhammadiyah University of Kupang is not awarded by students. Meanwhile, this policy grew hegemony to Christian students because they were obligated to learn Kemuhammadiyaan (AIK) and Arabic. As a result, multiculturalism and pluralism should be emphasized to reduce the misconception of multiculturalism at the Muhamadiyah University of Kupang.

\section{REFERENCES}

[1] S. Maryanto, 'Membangun Kampus Pluralisme', Cakrawala, Kupang, pp. 3-9, 2014.

[2] N. Demir and B. Yurdakul, 'The Examination of the Required Multicultural Education

Characteristics in Curriculum Design', Procedia Social and Behavioral Sciences, vol. 174, pp.

3651-3655, Feb. 2015, doi:

10.1016/j.sbspro.2015.01.1085.

[3] N. Efendi, 'Pengembangan Pendidikan Islam Plural-Multikultural', Ta'allum: Jurnal Pendidikan Islam, vol. 1, no. 1, pp. 13-28, 2013 , doi: 10.21274/taalum.2013.1.1.13-28.

[4] T. M. Tarjih, Tafsir Tematik al-qur'an tentang Hubungan Sosial antar Umat Beragama. Yogyakarta: Suara Muhammadiyah, 2000.

[5] A. Josefová, 'The Cultural Diversity as a Phenomenon of the Multicultural Society', Procedia - Social and Behavioral Sciences, vol. 152, pp. 1019-1021, Oct. 2014, doi: 10.1016/j.sbspro.2014.09.266.

[6] C. Kaygusuz, 'Psychological Counselling Within the Context of Globalization and Multiculturalism', Procedia - Social and Behavioral Sciences, vol. 47, pp. 895-902, Jan. 2012, doi: 10.1016/j.sbspro.2012.06.753.

[7] M. Syamsuddin, 'Gerakan Muhammadiyah dalam Membumikan Wacana Multikulturalisme: Sebuah Landasan Normatif-Institusional', JPM, vol. 1 , no. 2, p. 361, Jan. 2018, doi: 10.14421/jpm.2017.012-08.

[8] B. Biyanto, 'Pengalaman Muhammadiyah Membumikan Nilai-nilai Pluralisme', ISLAMICA: Jurnal Studi Keislaman, vol. 7, no. 2, pp. 318-339, Mar. 2013, doi: 10.15642/islamica.2013.7.2.318-339.
[9] A. Raza and H. Sohaib Murad, 'Learning in plural cultural context: Methodological framework for multiple pedagogic practices', Journal for Multicultural Education, vol. 8, no. 1, pp. 2-12, Jan. 2014, doi: 10.1108/JME-01-20140001.

[10] P. Eisenlohr, 'Religious Media, Devotional Islam, and the Morality of Ethnic Pluralism in Mauritius', World Development, vol. 39, no. 2, pp. 261-269, Feb. 2011, doi: 10.1016/j.worlddev.2009.11.026.

[11] R. A. Wortham, 'Religious pluralism, cultural continuity and the expansion of early Christianity: Stark revisited', The Social Science Journal, vol. 53, no. 4, pp. 573-580, Dec. 2016, doi: 10.1016/j.soscij.2016.07.006.

[12] C. Conle et al., 'The asset of cultural pluralism: an account of cross-cultural learning in preservice teacher education', Teaching and Teacher Education, vol. 16, no. 3, pp. 365-387, Apr. 2000, doi: 10.1016/S0742-051X(99)00067-0.

[13] M. N. Yasin, 'The Pluralism of Islamic Economic Law: Dialectic of Moslem and non-Moslem in the Development of Sharia Banking in Indonesia', JOURNAL OF INDONESIAN ISLAM, vol. 10, no. 1, Art. no. 1, Jun. 2016, doi: 10.15642/JIIS.2016.10.1.113-138.

[14] I. Cirik, 'Investigation of the Relations between Objectives of Turkish Primary School Curriculums and Multiculturalism', Procedia Social and Behavioral Sciences, vol. 116, pp. 74 76, Feb. 2014, doi: 10.1016/j.sbspro.2014.01.170.

[15] J. Reardon, 'How to Establish Pluralism at the Department Level****Presented at the 4th International Seminar of Heterodox Microeconomics unam, Mexico City, October 29-31,2012.', Economía Informa, vol. 383, pp. 522, Nov. 2013, doi: 10.1016/S01850849(13)71339-2.

[16] J. R. Rohe, H. Govan, A. Schlüter, and S. C. A. Ferse, 'A legal pluralism perspective on coastal fisheries governance in two Pacific Island countries', Marine Policy, vol. 100, pp. 90-97, Feb. 2019, doi: 10.1016/j.marpol.2018.11.020.

[17] B. Gökarıksel and A. Secor, 'Post-secular geographies and the problem of pluralism: Religion and everyday life in Istanbul, Turkey', Political Geography, vol. 46, pp. 21-30, May 2015, doi: 10.1016/j.polgeo.2014.10.006.

[18] J. A. Banks, An Introduction to Multicultural Education. Boston: Pearson Education, 2017.

[19] P. C. Gorski, 'What we're teaching teachers: An analysis of multicultural teacher education coursework syllabi', Teaching and Teacher Education, vol. 25, no. 2, pp. 309-318, Feb. 2009, doi: 10.1016/j.tate.2008.07.008. 
[20] Efendi and Suswanta, 'Politics of Education: Multiculturalism Practice in Universitas Muhammadiyah Kupang, NTT', Iseedu, vol. 1, no. 1, pp. 47-72, Nov. 2017, doi: https://doi.org/10.23917/iseedu.v1i1.5420.

[21] P. L. Berger and Luchmann, Tafsir Sosial Atas Kenyataan: Risalah Tentang Sosiologi Pengetahuan. Jakarta: LP3ES, 2019.

[22] J. W. Creswell, Qualitative Inquiry and Research Design. New Delhi: SAGE Publication, 2013.

[23] A. Aslan, Religious pluralism in Christian and Islamic philosophy: the thought of John Hick and Seyyed Hossein Nasr. Routledge, 2013.

[24] N. Altaş, 'Towards Comprehensive Religious Education (a Trial for New Research Ways within the Frame of Liberalism and Multiculturalism Concepts)', Procedia - Social and Behavioral Sciences, vol. 174, pp. 131-136, Feb. 2015, doi: 10.1016/j.sbspro.2015.01.637.

[25] N. Yustina, 'Implementasi Pendidikan Multikultural', Mar. 26, 2019.

[26] S. S. Djou, 'Penerapan Pendidikan Multikultural', Jul. 30, 2019.

[27] A. Kornelis, 'Kondisi Lingkungan Kampus UMK', Apr. 18, 2019.

[28] M. Bisik, 'Penerepan Pendidikan Multikultural', Aug. 05, 2019.

[29] A. Marina, 'Dakwah Kultural Muhammadiyah', Jun. 15, 2019.

[30] B. Kafomai, 'Pendidikan Multkultural', Apr. 14, 2020.

[31] J. A. Banks and C. A. M. G. Banks, Multicultural Education: Issues and Perspectives. Wiley, 2010.

[32] W. R. Jati, 'Toleransi Beragama dalam Pendidikan Multikulturalisme siswa SMA Katolik Sang Timur Yogyakarta', Jurnal Cakrawala Pendidikan, vol. 33, no. 1, Feb. 2014, doi: 10.21831/cp.v1i1.1863.

[33] P. Mareş, 'Tolerance and Universalism', Procedia - Social and Behavioral Sciences, vol. 149, pp. 537-541, Sep. 2014, doi: 10.1016/j.sbspro.2014.08.206.

[34] I. Paul-Binyamin and K. Haj-Yehia, 'Multicultural education in teacher education: Shared experience and awareness of power relations as a prerequisite for conflictual identities dialogue in Israel', Teaching and Teacher Education, vol. 85, pp. 249-259, Oct. 2019, doi: 10.1016/j.tate.2019.06.021.

[35] N. Szelei, L. Tinoca, and A. S. Pinho, 'Rethinking "cultural activities": An examination of how teachers utilized student voice as a pedagogical tool in multicultural schools', Teaching and Teacher Education, vol. 79, pp. 176-187, Mar. 2019, doi: 10.1016/j.tate.2018.12.020.
[36] B. Parekh, Rethinking Multiculturalism: Cultural Diversity and Political Theory. Yogyakarta: Kanisius, 2008.

[37] P. Freire, Pendidikan Kaum Tertindas. Jakarta: Pustaka LP3ES, 2013.

[38] J. P. Sartre, Eksistensialisme dan Humanisme. Yogyakarta: Pustaka Pelajar, 2002. 